\title{
FINANCIAL SUSTAINABILITY OF THE SOVEREIGN DEVELOPMENT AND INVESTMENT FUND (SDIF), BETWEEN THEORY AND PRACTICE
}

\author{
Cristian PARASCHIV and Cosmin TILEAGĂ \\ "Lucian Blaga" University of Sibiu, Faculty of Economic Sciences, cosmin.tileaga@ ulbsibiu.ro \\ "Lucian Blaga" University of Sibiu, Faculty of Law, cristi.paraschiv@icloud.com
}

\begin{abstract}
Theoretically and virtually, the investment and development fund projects and their activity prove to be sustainable in the long run, for example in Norway, where the additional income from the exploitation of natural resources in the North Sea is accumulated in an investment and development fund. In this case, it is about a revenue surplus that has been estimated to be accumulated and multiplied.

The project to establish a sovereign investment fund in Romania, which is based on an initially subscribed share capital, mainly constituted by contribution in kind, that is from participations held by the Romanian State in certain companies, underlines both theoretically and virtually, major differences compared to the Norwegian model and even to other European projects developed in this area.
\end{abstract}

KEY WORDS: SDIF, sovereign fund, investments, assets

JEL classification: G3 Corporate Finance and Governance, G30 General

\section{INTRODUCTION}

Theoretically and virtually, the investment and development fund projects and their activity prove to be sustainable in the long run, for example in Norway, where the additional income from the exploitation of natural resources in the North Sea is accumulated in an investment and development fund. In this case, it is about a revenue surplus that has been estimated to be accumulated and multiplied.

The project to establish a sovereign investment fund in Romania, which is based on an initially subscribed share capital, mainly constituted by contribution in kind, that is from participations held by the Romanian State in certain companies, underlines both theoretically and virtually, major differences compared to the Norwegian model and even to other European projects developed in this area.

The effort of the Romanian State to capitalize this fund by accruing participation that it holds, has a significant financial impact in terms of the amounts that shall no longer be collected as dividend / yearly income received by it from the point of view of the shareholder's capacity.

The financial sustainability of the activity of the Sovereign Development and Investment Fund (SDIF) highlights that, in practice, the profitability element of this project can only be recorded over the medium and long term, the investment projects considered being characterized as long-term, according to the premises and objectives they have.

\section{THEORETIC ASPECT REGARDING SOVEREIGN FUNDS TO BE INCORPORATED IN ROMANIA}

In terms of the general theoretical plan, it is worth mentioning that, based on the Governing Program (http://www.cdep.ro/pdfs/oz/Program\%20de\%20Guvernare.pdf ) approved by the Romanian Parliament, for 2017-2020, the Romanian Government has proposed the creation of new public investment instruments, namely the establishment, starting with 2017, of a sovereign investment fund (SDIF) for the efficient administration and capitalization of minority State's participations. SDIF's objective - economic development through infrastructure investments and strategic companies, strengthening the active role of the State by properly managing the minority participations and obtaining liquidity from bonds issue, capitalizing certain assets, dividends and other sources attracted to the investment projects.

Also based on this program, it was considered that alongside SDIF, at latest in the second semester of 2017, a National Development Fund (NDF) shall be created, which will include companies the State holds participations in and are currently managed by the Authority for State's Assets Management (ASAM), but also state companies that may not be included in the SDIF because of the European ban which stipulates that in some cases the production and distribution companies cannot be managed by the same entity, thus avoiding the monopoly behavior. As a result of these regulations, Transelectrica and Transgaz shall be managed and held by the NDF, and Hidroelectrica or Romgaz by SDIF, and ASAM is to be closed down. Like SDIF, NDF will remain in the exclusive property of the Romanian State throughout its operation period.

The Governing Plan considers giving up the complex that many Romanian governments had, that is that there are some things that cannot be done in our country, although many states have done them long before and with very good results.

Thus, based on the experience of some states as Norway, France, Italy or Poland, the Romanian Government proposed the incorporation of a Sovereign Development and Investment Fund (SDIF), which shall consist mainly of the profitable state-owned companies, whose value shall exceed 10 billion $€$.

As considered by the Romanian Government, according to the Governing Plan, SDIF would use the revenues from dividends of the portfolio companies as well as the revenues from bond issues or the sale of non-performing assets (holiday houses, hotels - belonging to companies whose business is entirely different), the purpose of the fund being to develop or build from scratch, business in priority areas for the Romanian State, which shall economically support itself (with a certain degree of 
profitability), alone or together with other investment funds or private investors.

In this regard, it was estimated that 10 billion $€$ would enter Romania's economy in the next 4 years through SDIF, the activity of this fund leading to the emergence of many factories in agriculture and industry, but also to the capitalization of some companies such as Tarom, CFR, Constanţa Navy Site, CEC, Nuclearelectrica so that they may expand their activity or, as the case may be, acquire new capabilities: fleet of airplanes, ships, trains.

It was anticipated that the largest investments of SDIF in the first 4 years of incorporation would be made in the health care area by building up a republican hospital and 8 regional hospitals. The total amount funded by the SDIF is estimated at 3.5 billion $€$.

3 more billion $€$ was taken into account by the government for the construction of highways and fast railways, with priority the highways that may not be completed or launched from European funds by 2020, such investments being made by SDIF along with other international banks, BEI, BERD and the World Bank on the basis of public-private partnerships, these highways being held for a period of 30 years, after which they shall be ceded back to the Romanian state, insofar the state budget shall have available liquidities to buy them back.

Examples of such highways as well as fast railway to be funded by the State budget and by SDIF are:

a highway crossing the mountains between Transylvania and Moldova (Târgu Mureş - Iaşi);

a highway through Southern Romania, connecting Transylvania to Oltenia and Țara Românească (Timişoara Bucharest);

a highway through the Prahova Valley (Comarnic - Braşov) and a highway connecting Moldova to Ţara Românească (Iaşi Bucharest);

rehabilitation of some railway and their modernization from West - Bucharest, Chişinău - Iaşi - Bucharest, Bucharest Constanta, Bucharest - Braşov.

Another developed industry that wants to be funded by the government through SDIF shall be the weaponry by extending the capabilities of the existing plants.

The Government of Romania anticipated that although the state budget would initially decrease by 2.6 billion 1
The Government of Romania anticipated that although the State budget would initially be reduced by 2.6 billion lei, money that shall no longer be collected from the state companies' dividends due to the strong economic activity of the SDIF, and taxes and levies amounts of approximately 9 billion lei would be collected to the budget. Thus, in 2020, the annual surplus to the State budget brought by SDIF will be at least 6 billion lei.

By the incorporation of SDIF it is anticipated the fact that by these investments there shall be created 850,000 new full-time jobs with an economic growth rate of over $5 \%$, as more than 50,000 of new jobs will be created in the health care area through the 9 large hospitals built by 2020 .

At the same time, the government intends that Eximbank become a Development and Investment Bank (DIB), thus expanding its scope of business, in addition to supporting exports and supporting the financing of major public and private investment projects for CEC Bank taking into account the extension of the SME action and farming area so that it may support the national programs developed in partnership with the Romanian government and also in order to finance much more than it does now, small and medium-sized businesses in IT, tourism, constructions, services, manufacturing, crafts, etc. as well as farmers or those who want to invest in farming.

For the two banking institutions presented to be able to reach the described level, the Government of Romania has proposed to capitalize them with priority through SDIF.

\section{PRACTICAL APPROACHES FOR THE INCORPORATION OF THE SOVEREIGN DEVELOPMENT AND INVESTMENT FUND}

The intention to incorporate a sovereign fund materialized in 2018 by the adoption by the Romanian Parliament of the Law on the incorporation of Fondul Suveran de Dezvoltare și Investitii - S.A. and for the amendment of some normative acts (https://www.juridice.ro/wp-content/uploads/2017/08/Proiect-

52.pdf), called SDIF, a Romanian legal person organized as a joint stock company, according to the provisions of the Companies Law no. 31/1990, republished, with the subsequent amendments and completions and of its articles of incorporation.

The share capital of SDIF fully subscribed at the date of its incorporation was intended to consist of a contribution in kind represented by the shares of a number of 28 companies (Table 1) to which the Romanian State was a shareholder as well as by cash contribution in value of 1,850,000,000 lei.

Table 1. List of share packages as contribution in kind to the initial share capital of SDIF according to the law adopted by the Romanian Parliament

\begin{tabular}{|c|c|c|c|}
\hline No. & Company name & SRC & $\begin{array}{c}\% \text { direct } \\
\text { holding }\end{array}$ \\
\hline 1. & engie românia s.a. & 13093222 & 34.0065 \\
\hline 2. & societatea de distribuţie şi furnizare a energiei electrice- electrica s.a. & 13267221 & 48.7800 \\
\hline 3. & delgaz grid s.a. & 10976687 & 13.5147 \\
\hline 4. & e.on energie românia s.a. & 22043010 & 31.8200 \\
\hline 5. & biofarm s.a. & 341563 & 1.1619 \\
\hline 6. & chimcomplex s.a. & 960322 & 12.8956 \\
\hline 7. & omv petrom s.a. & 1590082 & 20.6390 \\
\hline 8. & telekom românia communications s.a. & 427320 & 45.9897 \\
\hline 9. & antibiotice s.a. & 1973096 & 53.0173 \\
\hline 10. & compania naţionala pentru controlul cazanelor, instalaţiilor de ridicat şi & 27787860 & 100 \\
\hline 11. & recipientelor sub presiune s.a. & 12397185 & 100 \\
\hline
\end{tabular}




\begin{tabular}{|c|c|c|c|}
\hline 12. & societatea naţionala a sarii s.a. & 1590430 & 51 \\
\hline 13. & iar s.a. & 1132930 & 72.1900 \\
\hline 14. & oil terminal s.a. & 2410163 & 59.6222 \\
\hline 15. & cupru min s.a. & 11551757 & 100 \\
\hline 16. & compania naţionala unifarm s.a. & 11653560 & 100 \\
\hline 17. & societatea naționala a apelor minerale s.a. & 1590040 & 100 \\
\hline 18. & $\begin{array}{c}\text { compantionala administraţia porturilor } \\
\text { dunArii mariTime s.a. }\end{array}$ & 11776466 & 92.3000 \\
\hline 19. & compania de investiții pentru turism s.a. & 24979799 & 100 \\
\hline 20. & societatea naţionala de gaze naturale romgaz s.a. & 14056826 & 70.0071 \\
\hline 21. & societatea de producere a energiei electrice in hidrocentrale hidroelectrica s.a. & 13267213 & 80.0561 \\
\hline 22. & compania naţionala aeroporturi bucureşti s.a. & 26490194 & 80 \\
\hline 23. & societatea naţionala nuclearelectrica s.a. & 10874881 & 82.4959 \\
\hline 24. & compania naţionala imprimeria naţionala s.a. & 2779625 & 100 \\
\hline 25. & compania naţionala administraţia porturilor maritime s.a. & 11062831 & 80 \\
\hline 26. & societatea de administrare a participațiilor in energie s.a. & 33134190 & 100 \\
\hline 27. & conpet s.a. & 1350020 & 58.7162 \\
\hline
\end{tabular}

This law draft has no longer been promulgated by the President of Romania in the context in which, by Decision no. 531 / 2018 (http://www.cdep.ro/proiecte/2018/200/30/6/dcc531.pdf), the Romanian Constitutional Court found that the Law on the incorporation of the Sovereign Investment and Development Fund is unconstitutional, in which regard this normative act has no longer entered into force.

At the date of this document, two years after the intention to incorporate the SDIF and after finding the unconstitutionality of the SDIF incorporation law, the Ministry of Public Finances promotes a new normative act materialized in a draft Government Decision (http://www.mfinante.gov.ro/) on the basis of which the Sovereign Fund to be incorporated, prior to this approach, the Government of Romania having approved the GEO 100/2018 to regulate some measures regarding the general framework enforceable upon sovereign development and investment funds.

The Government Decision draft is to regulate the conditions for the organization and functioning of the Sovereign Development and Investment Fund - S.A. (SDIF) to be organized as a joint stock company, in accordance with the provisions of the Companies Law no. 31/1990, republished, with the subsequent amendments and completions, of the Government Emergency Ordinance no. 100/2018 to regulate some measures regarding the general framework enforceable upon the sovereign development and investment funds, the Romanian State through the Ministry of Public Finance (MPF) will be the sole shareholder of SDIF throughout its lifetime.

It is taken into consideration that Fondul Suveran pentru Dezvoltare și Investiții - S.A. shall have as a direct objective the support of the economic development through investments in competitive areas, which entails a multiplier effect in the economy, following the attraction of capital and sources from the financial market.

According to the Government Decision draft, in order to fulfil its main business, SDIF is authorized under the law to participate in the incorporation of companies / funds as a sole shareholder or together with other shareholders, to finance the activity of the companies whose shareholding it is part of by participation ni the share capital increase, through loans or other forms of financing, and to guarantee loans for these companies, to trade shares of its own portfolio through sale and purchase operations, to dispose of the financial instruments in its own portfolio in accordance with their own investment policies.

The Romanian Government aims to achieve the following benefits through the incorporation of SDIF:

a) to create sustainable sources of financing for the materialization of projects in various economic domains, in conditions of economic profitability and financial sustainability; b) an effective catalyst role to attract private funds (banks, retirement funds, investment funds) which, together with own funds, shall assure the finance of some investment projects whose implementation will lead to an economic multiplier effect both horizontally, and vertically. Depending on the market conditions and the characteristics of the funded project, the SDIF will be able to reach attractive multiplication factors, the financial multiplication effect being obtained by attracting capital from institutional and private investors, both in the form of capital and under the form of borrowed capital;

c) support Romania's efforts to achieve the emerging market status for the domestic capital market by increasing liquidity as a result of the listing the companies in the SDIF portfolio on the Bucharest Stock Exchange and AeRO;

d) increase the absorption rate of the European nonreimbursable funds by participating in the co-financing of some investment projects.

According to the normative act draft, the SDIF financing will be made from income from dividends received from the companies in its portfolio, from those resulting from operations with its own financial instruments and from those issued by other entities, from income from the sale of stock packages in the portfolio, loans, including through the issuance of bonds, but also from other sources provided by law. Show moreShow less

The SDIF Strategy is developed by the Directorate, endorsed by the Supervisory Board and approved by the General Meeting of Shareholders on the basis of guidelines approved in advance by Government Decision and is accompanied by a business plan and an economic- financial framework to substantiate it, presented as annexes to the strategy.

The strategy is correlated with a set of medium to long-term performance indicators set by the general shareholders' meeting prior to the elaboration of the strategy by the SDIF management and considers the following development areas and activities:

a) companies' financing at different stages of development, indirectly through dedicated funds, regardless of the structure of 
the shareholders, if these enterprises are relevant for a particular economic / industrial sector;

b) financing Romanian companies of strategic importance, respectively the development of key sectors, in which the Romanian companies have the chance to obtain a competitive advantage at a global level;

c) investments in industry, agriculture, services, commerce, constructions;

d) investments in infrastructure projects;

e) financing start-ups and enterprises at an early stage of development;

f) job creation in a sustainable way, geographically a priority in less developed area and economically a priority in areas with high potential for economic growth; g) stimulate innovation and new technologies;

h) develop long-term human and social capital;

i) increase the competitiveness of Romanian economy;

j) pursue the energy strategy;

k) capital markets;

1) companies abroad;

m) other areas and development activities that are of interest to the national economy.

The Government Decision considers an initial share capital of SDIF, set at 19,111,850,332 lei, consisting of a cash contribution of 9 billion lei and a contribution in kind represented by the nominal value shares of $10,111,850,332$ lei, held by the Romanian State in 28 companies (Table 2).

Table 2. List of companies whose share packages are contribution in kind to the initial share capital of SDIF

\begin{tabular}{|c|c|c|c|c|c|}
\hline NO. & Company name & SRC & $\begin{array}{c}\text { Total Share Capital } \\
\text { Romanian State } \\
\text { (lei)* }\end{array}$ & $\begin{array}{l}\% \text { Share } \\
\text { Capital } \\
\text { Romanian } \\
\text { State }\end{array}$ & $\begin{array}{c}\text { Total estimated market } \\
\text { value of the participation } \\
\text { held by the Romanian } \\
\text { State (lei) } \\
\text { (https://www.profit.ro) }\end{array}$ \\
\hline 1 & Engie Romania S.A.*** & 13093222 & $73,713,200.00$ & $37.00 \%$ & $1,370,000,000.00$ \\
\hline 2 & $\begin{array}{c}\text { Societatea de Distributie si } \\
\text { Furnizare a Energiei Electrice - } \\
\text { "ELECTRICA" S.A.** }\end{array}$ & 13267221 & $1,687,511,850.00$ & $48.78 \%$ & $1,740,000,000.00$ \\
\hline 3 & Delgaz Grid S.A.*** & 10976687 & $104,503,450.00$ & $13.51 \%$ & $375,800,000.00$ \\
\hline 4 & E.ON Energie Romania SA*** & 22043010 & $58,804,970.00$ & $31.82 \%$ & $300,400,000.00$ \\
\hline 5 & Chimcomplex SA** & 960322 & $27,305,181.54$ & $9.21 \%$ & $108,200,000.00$ \\
\hline 6 & OMV Petrom SA** & 1590082 & $1,169,069,441.80$ & $20.64 \%$ & $4,000,000,000.00$ \\
\hline 7 & $\begin{array}{c}\text { Telekom Romania } \\
\text { Communications S.A. }\end{array}$ & 427320 & $146,460,920.00$ & $45.99 \%$ & \\
\hline 8 & CN "Loteria Romana" SA & 12397185 & $42,611,725.00$ & $100.00 \%$ & \\
\hline 9 & IAR SA** & 1132930 & $30,626,220.00$ & $64.89 \%$ & $97,300,000.00$ \\
\hline 10 & Oil Terminal SA** & 2410163 & $34,725,797.30$ & $59.62 \%$ & $47,360,000.00$ \\
\hline 11 & $\begin{array}{l}\text { CN Administratia Porturilor } \\
\text { Dunarii Maritime SA } * * *\end{array}$ & 11776466 & $849,470.00$ & $80.00 \%$ & $16,000,000.00$ \\
\hline 12 & $\begin{array}{l}\text { SN de Gaze Naturale } \\
\text { "ROMGAZ" SA** }\end{array}$ & 14056826 & $269,823,080.00$ & $70.01 \%$ & $8,350,000,000.00$ \\
\hline 13 & $\begin{array}{l}\text { Societatea de producere a } \\
\text { energiei electrice in } \\
\text { hidrocentrale } \\
\text { "HIDROELECTRICA" } \\
\text { S.A.*** } \\
\end{array}$ & 13267213 & $3,588,429,260.00$ & $80.06 \%$ & $17,100,000,000.00$ \\
\hline 14 & CN "Aeroporturi Bucuresti" SA & 26490194 & $115,017,720.00$ & $80.00 \%$ & $3,400,000,000.00$ \\
\hline 15 & SN "Nuclearelectrica" SA** & 10874881 & $2,487,366,190.00$ & $82.50 \%$ & $2,360,000,000.00$ \\
\hline 16 & $\begin{array}{c}\text { CN "Imprimeria Nationala" } \\
\text { SA** }^{* *}\end{array}$ & 2779625 & $561,700.00$ & $100.00 \%$ & \\
\hline 17 & Conpet SA** & 1350020 & $16,775,127.60$ & $58.72 \%$ & $402,000,000.00$ \\
\hline 18 & $\begin{array}{c}\text { SN "Aeroportul International } \\
\text { Timisoara-Traian Vuia-" } \\
\text { SA*** }\end{array}$ & 11178217 & $1,280,640.00$ & $80.00 \%$ & $80,000,000.00$ \\
\hline 19 & $\begin{array}{c}\text { Societatea de Tratament } \\
\text { Balnear si Recuperare a } \\
\text { Capacitatii de Munca } \\
\text { "T.B.R.C.M" S.A. }\end{array}$ & 15619634 & $10,629,732.50$ & $100.00 \%$ & \\
\hline 20 & $\begin{array}{l}\text { CN Administratia Porturilor } \\
\text { Dunarii Fluviale S.A.**** }\end{array}$ & 1284717 & $1,102,160.00$ & $80.00 \%$ & $7,000,000.00$ \\
\hline 21 & $\begin{array}{l}\text { Compania Nationala pentru } \\
\text { Controlul Cazanelor, } \\
\text { Instalatiilor de Ridicat si } \\
\text { Recipientelor sub Presiune - } \\
\text { (CNCIR) SA }\end{array}$ & 27787860 & $32,007,800.00$ & $100 \%$ & \\
\hline 22 & Cupru Min SA Abrud & 11551757 & $24,184,800.00$ & $100 \%$ & \\
\hline 23 & $\begin{array}{c}\text { Societatea Nationala a Sarii } \\
\text { SA*** }\end{array}$ & 1590430 & $20,877,570.00$ & $51 \%$ & $260,000,000.00$ \\
\hline
\end{tabular}




\begin{tabular}{|c|c|c|c|c|c|}
\hline 24 & Romaero** & 1576401 & $9,850,842.50$ & $57 \%$ & $78,000,000.00$ \\
\hline 25 & $\begin{array}{c}\text { CN "Administratia Porturilor } \\
\text { Maritime" - S.A.Constanta*** }\end{array}$ & 11062831 & $106,325,150.00$ & $80 \%$ & $976,000,000.00$ \\
\hline 26 & $\begin{array}{c}\text { CN Administratia Canalelor } \\
\text { Navigabile SA }\end{array}$ & 11087755 & $8,126,400.00$ & $80 \%$ & $58,400,000.00$ \\
\hline 27 & Antibiotice SA** & 1973096 & $35,592,513.50$ & $53 \%$ & $174,700,000.00$ \\
\hline 28 & CN Unifarm S.A. & 11653560 & $4,272,030.00$ & $100 \%$ & $41,301,160,000.00$ \\
\hline \multicolumn{7}{|c|}{$10,108,404,941.74$} \\
\hline
\end{tabular}

Within the Government Decision draft, it is taken into consideration that the value related to the contribution in kind to the subscribed and paid-up share capital is to be established on the basis of the shares assessment report prepared by an assessment expert appointed by the National Trade Register Office upon request of the Ministry of Public Finance.

Thus, the value of the in-kind contribution to the subscribed share capital of SDIF is determined prior to the incorporation of the SDIF within maximum 45 days from the date of the appointment of the expert authorized by the National Trade Register Office through the assessment methods established by the Government Decision, taking into consideration the fact that the value of the contribution in-kind to the initial share capital of SDIF is calculated at the nominal value of the shares, which may differ from the value of the contribution in kind determined by the assessment expert.

The financial resources needed to cover the cash payments in the amount of 9 billion lei shall be provided by the Ministry of Public Finances from the privatization revenues in lei and / or foreign currency available in the balance of the state treasury account. An amount of 0.5 billion lei from the privatization revenues in lei is due to be wired at the time of the incorporation of SDIF, the share capital difference is to be paid within maximum 12 months from the date of the registration of SDIF, from the privatization revenues in foreign currency. The payments from the foreign currency revenues shall be made in instalments, in lei, at the exchange rate valid on the date of the payment of each instalment, notified by the National Bank of Romania. The instalments are paid by the Ministry of Public Finances within 15 working days from the receipt of the SDIF application formulated in accordance with the SDIF strategy approved by the general shareholders meeting, prepared on the basis of some guidelines previously approved by Government decision.

The shares packages are to be transferred to SDIF's ownership, and it may freely dispose of them as its own property under the law.

The decision to dispose of the assets and shares that constitute the initial share capital of SDIF, is to be taken in line with the SDIF strategy and it is based on a cost / benefit analysis of the use of this funding source from asset / share disposal for strategy implementation after depletion of all other financing instruments provided by law, maintaining the value of the net asset of SDIF at the levels set by the SDIF strategy and meeting the indebtedness thresholds and the profitability and risk objectives in the strategy.

The compliance with these requirements regarding the disposal of shares and assets, including those contributing to the share capital of SDIF, took into consideration, on one hand the limitation of the economic risks entailed from the unjustified alienation of shares to strategic companies and, on the other hand, the assurance of the independence and decision-making autonomy of SDIF on the assets held, a condition to be met for classification outside the public administration sector.

Specific requirements for the alienation of the assets held by SDIF are provided only for those that have contributed to the initial share capital, as the other assets acquired through SDIF's activity are own assets for which the fund should have full decisional autonomy.

The SDIF management shall be made in a dual system by a Supervisory Board and a Directorate, in accordance with the provisions of Law no. 31/1990, republished, as subsequently amended and supplemented. The Supervisory Board consists of 9 members in order to observe the corporate governance best practices and avoid the classification of SDIF in the public administration sector.

\section{THE FINANCIAL SUSTAINABILITY OF THE SOVEREIGN DEVELOPMENT AND INVESTMENT FUND (SDIF), BETWEEN THEORY AND PRACTICE}

In the context of the incorporation of SDIF, whose organization and operation is subject to the provisions of the company law, the following are important to be noticed in the analysis of the sustainability of SDIF's:

the sustainability of its own activity and the coverage of the current operating costs, including those generated by the period immediately following the incorporation, but also the obtaining of profit for the Romanian State, which shall be cashed as dividend;

the sustainability of the activity of the companies the SDIF is to hold participations in, so that their activity may be profitable and indirectly leading to collecting a dividend by SDIF;

the sustainability of the partnerships that SDIF will establish with other investors in order to develop some investment projects;

the sustainability of projects SDIF is to invest in.

We appreciate that in practice, immediately after incorporation, the SDIF activity is to be focused, at least for a period of 6-12 months, on elements of logistics organization and establishment of the organizational structure of the fund, on attracting qualified personnel, on the elaboration and developing procedures.

Concurrently or subsequently with such activities, it is necessary within SDIF the development of some analyses and studies based on which SDIF may identify the investment areas in 
which, on the basis of efficiency and effectiveness, but also profitability criteria, it may focus the investment activity. In the context of SDIF's activity, it is also important to identify the sources of co-financing of the investment projects of SDIF, respectively the potential partners and the minimum conditions that they must meet in terms of the projects they are to participate in.

In these activities related to the incorporation of SDIF and the support of the operationalization measures, it is necessary and expected that the structures within the fund to be operational as well and to make efforts to monitor, to render more efficient and to support the management and activity of the companies in the portfolio, but also to maintain and support their profitability.

The measures ordered by the Romanian State during year 2018 in relation to the companies transferred to SDIF, materialized in the anticipated collection of some dividends, which would normally have had to be transferred in 2019, with the conclusion and approval of the financial statements, but also the collection by the Romanian State of some amounts due to some provisions that led to the reduction of liquidity reserves existing within these companies, indirectly led to the reduction of the amounts that SDIF, as new shareholder of these companies, would have to collect during its first year of operation.

In other words, in 2019, for year 2018, the dividend to be collected by SDIF, from the point of view of the shareholder capacity in the 28 companies, it was greatly affected.

From this perspective, SDIF's revenues, anticipated in the first phase of its operation as coming from the collection of dividends from the companies in its own portfolio, are found to be much lower than expected, a situation that would require for year 2019 a policy of anticipated collection of the profit from the companies it holds shares in or the collection thereof in 2020 after completing the 2019 financial year.

Corroborated with the financial sustainability aspects analysed above, the investment plans and the operational expenses of the companies in the SDIF portfolio are also considered, their activity being affected by the financial effort made on the occasion of the payment of the dividend to the Romanian state, including the payment of some sums coming from the reserves of these companies to the Romanian state, aspects which indirectly affect the element of profitability of their current activity, the revenues anticipated by SDIF to be collected, also being affected.

The liquidations available to SDIF since its incorporation amounts to 0.5 billion lei, the sum coming from the privatization revenues to be wired as cash contribution to the Fund's share capital, the total of the available cash being 9 billion lei, which are to be wired later on, based on some requests formulated by SDIF within 18 months.

Upon the incorporation of SDIF, it was anticipated that from year 2019 onwards the impact on State budget revenues would be estimated at 4.7 billion lei, in the meaning of reducing the revenues to the state budget with the value of the dividends to be collected by SDIF for the shares transferred in its portfolio.

Another effort of the State is the capitalization of SDIF with the 9 billion lei, revenues from privatization, constituted as cash contribution to the fund's share capital.

In supporting and justifying this effort, the Romanian State considered to recover these amounts in the years following the first year of operation by collecting the dividends that SDIF would pay to the state as sole shareholder on the occasion of the distribution of profits and the establishment of dividends.

On the basis of the available data, in absence of a strategy and management / business plan of SDIF, we find that the State's expectations consider a short term SDIF profitability, that is for a period of 12-18 months after the incorporation thereof.

Important aspects related to the incorporation of SDIF also take into account the fact that the real value of the contribution in kind to the share capital of SDIF is estimated to be much higher than the initial values, namely the amount of 10,11 billion lei.

Taking into account the market value of the Romanian Stateowned share packages in the 28 companies, the real value of the contribution in kind to the SDIF's share capital may rise and possibly exceed 41 billion lei.

In determining this amount, it was taken into account the estimated value of the participation held by the Romanian State in the listed companies, which was established on the basis of the data existing with BSE and of the estimated value of the participation held by the Romanian State in companies where the co-shareholder, Fondul Proprietatea conducted its own assessments on the occasion of regular reportings.

From the analysis of the above-presented data, we find that the sustainability elements of SDIF and of its activity greatly impacts on both the share capital held by the Romanian State as participations as well as its budget and its execution by noncollecting some dividends as a result of the transfer to SDIF of the ownership right held in the 28 companies.

In the analysis of the sustainability of the SDIF's incorporation by the Romanian State, it was not also revealed the impact of the transfer of the ownership right on some shares largely held in national companies and enterprises, a measure that may involve legal aspects and consequences with direct impact on the activity and profitability of these public enterprises.

The very wide spectrum of objectives that SDIF proposed, exemplary being the financing projects for the construction of hospitals or the construction of highways, including the support of the activity of some companies or fields of activity in which the need for investments is found, require the allocation of investments on medium and long term, the recovery period thereof being quite large, respectively 5-10 years.

Based on a brief analysis, however, it is found that the amortization of the investment in such projects, as well as obtaining profit, can only be achieved in the medium and long term.

\section{CONCLUSIONS}

In the context of the presented, it may be appreciated that beyond the negative financial impact that the Romanian state is to feel along with the incorporation of SDIF, the activity and the projects of the fund incorporated as such, may be affected by the lack of dividends collection, which are mainly a source of support of the current activity, but also a source of financing of the projects that are to be implemented by SDIF.

The non-collection of some dividends may represent a real short and medium-term problem for the Romanian State, which coincides with a financial situation in which, against the background of some systemic perturbations generated at international and European level, the elements of financial predictability are addressed in a reserved note. 
Thus, in the context of incorporating the SDIF, the Romanian State is in a position to identify financial policies and solutions, including other sources of revenues to the state budget, in order to compensate at least for the short and medium term the budget deficit generated by the establishment of this fund.

From this perspective it is to be anticipated that SDIF will encounter difficulties since its incorporation, determined by the necessary liquidities for its own functioning, as well as by the liquidities needed to sustain the necessary liquidities for supporting the investment projects that are to be identified and developed by it, aspects directly conditioned by a strategy and a business plan to take into account investment projects whose profitability and multiplication factor may only be achieved in the medium and long term.

It is to be appreciated that the SDIF's sustainability, indirectly its profitability element, cannot be seen from the perspective of the possible gains that the Romanian State would indirectly collect from the construction of hospitals or highways, as well as through the generation of jobs, the main profitability indicator of the fund being the dividend that the Romanian State would collect from its perspective of sole shareholder.

At least on the basis of the existing data and in the absence of analyses and strategies, SDIF's sustainability elements are in a reserved note, which is directly conditioned by the identification of the sources of income needed to support their own activities, the activities of their own portfolio companies and investment projects activity.

Such sources of income, absolutely necessary in the short and medium term, given the portfolio of participations held by the 28 companies, indirectly the subscribed share capital in kind, can be obtained on the basis of some loans, financing from investors, issuing of bonds or by selling ownership interests.

Such an approach emphasizes the reservation note on the SDIF sustainability, an in this regard it is identified the occurrence of a special issue regarding the economy, efficiency and effectiveness of the SDIF incorporation, as well as the risk of exposure by the Romanian State of both the participations held in the 28 companies transferred to the fund, as well as the participation held by SDIF.

\section{REFERENCES:}

1. Dragomir V., Guvernantă corporativă şi sustenabilitate în Uniunea Europeană.(2010) Editura Economică, Bucureşti, p. 49;

2. Fassin Y., (2008) The Stakeholder Model Refined, Journal of Business Ethics, p. 113-135;

3. Feleagă, N., Feleagă L., Dragomir V.D., Bigioi D. (2011), Guvernanta corporativă în economiile emergente: căzul României. Economie teoretică şi aplicată, Volumul XVIII (2011), No.9(562), pp. 3-15;

4. Rusu P. (2013), Management orientat spre acţionari (II), RMEE, Revista de Management şi Inginerie Economică. Nr. 2/2013;

5. Rusu P. (2013), Management orientat spre acţionari (III), RMEE, Revista de Management şi Inginerie Economică. Nr. 4/2013;

6. Feleagă, N. Feleagă, L. Dragomir, V. Bigioi, (2011), Guvernanta corporativa în economiile emergente: cazul României, Economie teoretică şi aplicată, voi. XVIII, nr. 9;

7. M.Wielechowsky, (2011) "General Government deficit and public debt in EU member states", Warsaw University of Life Science SGGW, working paper no. 4; 